\title{
O “insustentável” peso da moradia: uma análise socioambiental sobre o processo de formação territorial do Bairro Jardim Social - Paranaguá (PR)
}

\author{
The "unbearable" burden of habitation: a socio-environmental analysis of the 'Jardim \\ Social' neighboorhood territorial conformation - city of Paranaguá (PR)
}

\author{
Marcelo Cunha Varella ${ }^{1}$ \\ Roberto Martins de Souza ${ }^{2}$ \\ Letícia Ayumi Duarte ${ }^{3}$
}

\begin{abstract}
Resumo
O presente artigo visou refletir sobre a questão fundiária de Paranaguá a partir do caso concreto vivido pelos moradores da ocupação denominada Jardim Social, que atualmente estão ameaçados de sofrer uma "reintegração de posse". Nesse sentido, apresentamos um debate teórico-temático e jurídico sobre os aspectos da urbanização parnanguara, amparado no método da pesquisa-ação, a fim de apresentar um contradiscurso capaz de enfrentar os argumentos que embasam tal pedido de reintegração de posse e que levam à desterritorialização desses sujeitos e à reprodução do padrão histórico da fragmentação socioespacial vivida na cidade, marcada pelo parco acesso à moradia regularizada e à ampliação da rede urbana sobre áreas ainda conservadas. Por fim, iluminamos ações que podem ser feitas pelo poder público parnanguara, visando enfrentar o grave problema fundiário vivenciado pelos moradores mais pobres da cidade.
\end{abstract}

Palavras-chave: Ordenamento territorial. Ambientalização. Direito à cidade.

\begin{abstract}
This article aimed to reflect on the land issue of Paranaguá, based on the concrete case lived by the residents of the occupation called Jardim Social, who are currently threatened with a reintegration of land tenure. In this sense, we present a theoretical-thematic and juridical debate on the aspects of the city urbanization, supported by the action research method, in order to present a counter-discourse, able to face the arguments that support this application for reintegration of ownership, and which lead to the de-territorialization of these subjects and the reproduction of the historical pattern of the sociospatial fragmentation lived in the city, marked by the scarce access to regularized housing and the expansion of the urban network over areas still preserved. Finally, we enlighten actions that can be done by the city public power, aiming to face the serious land problem experienced by the poorest residents of the city.

Keywords: Land use planning. Environmentalization. Right to the city.

\footnotetext{
${ }^{1}$ Doutor em Geografia (UFPR). Professor do curso de Licenciatura em Educação do Campo: Ciências da Natureza da Universidade Federal do Paraná, Setor Litoral (UFPR Litoral). E-mail: mvarella@ hotmail.com

${ }^{2}$ Doutor em Sociologia (UFPR). Professor do curso de Ciências Sociais do Instituto Federal do Paraná (IFPR). E-mail: roberto.souza@ifpr.edu.br

${ }^{3}$ Doutora em Geografia (UFPR). Atualmente leciona no curso de Gestão e Empreendedorismo (UFPR Litoral). E-mail: leticia27duarte@gmail.com
} 


\section{Introdução}

Antes de qualquer ponderação ou apontamento acerca da temática aqui posta, vale ressaltar que este artigo desenrola questões que também foram abordadas em parecer técnico ${ }^{4}$ (VARELLA; SOUZA, 2017) escrito com a finalidade de atender à solicitação do Defensor Público Wisley Rodrigo dos Santos, emitida a partir do Ofício 50/2017 (PARANÁ, DPPR, 2017), datada de 24 de julho daquele ano. Ainda que tenha sido escrito à Defensoria Pública do Estado do Paraná (DPPR), deve-se ter em mente que as reflexões contidas neste documento decorrem de metodologia "pesquisa-ação" (BRANDÃO; BORGES, 2007) utilizada em trabalhos acadêmicos junto com o movimento social que vem se organizando pelo direito à cidade em Paranaguá. Mais precisamente, o presente debate se desdobra sobre a organização popular que se faz atualmente em torno da luta pelo direito à moradia no Bairro Jardim Social. Destarte, todos os argumentos utilizados neste artigo têm como base os discursos dos moradores desse Bairro que, de alguma forma, orbitavam em torno do tema da "regularização fundiária". Em suma, a participação popular, assim, funciona, aqui, como um dos principais fundamentos desta pesquisa - por uma questão de recorte, neste artigo não exporemos minúcias desse processo, uma vez que a ideia central é iluminar o contradiscurso movido pelos moradores, com fins de enfrentar os argumentos perpetrados pelo Ministério Público Estadual sobre a situação fundiária do Bairro.

Que se pese que, durante os processos pedagógicos de "investigação-educação-ação" que envolveram esta pesquisa, os moradores se viram em meio a um cenário de conflito territorial, marcado pela eminente ameaça de sofrerem uma "desterritorialização" (HAESBAERT, 2014), posta em marcha por atores que, por diferentes interesses, motivações e argumentos, postam-se contra a permanência dos moradores no bairro. Dentre esses atores que, nessa conjuntura, colocaram-se contrários ao projeto de regularização fundiária dos moradores, encontra-se o Estado, representado pelo Ministério Público Estadual, autor de uma ação civil que visa, entre outras coisas, realizar uma "reintegração de posse" na área - ou seja, pretende desterritorializar os moradores. Frise-se que o Estado, em nenhuma de suas esferas e instâncias, possui um plano para "reterritorializar" os moradores em uma nova área; ao mesmo tempo, ainda que pareça surreal, tal processo de desterritorialização aparece como justificativa ao "desenvolvimento sustentável" da cidade - pelo que coloca o Ministério Público, os moradores do bairro ocuparam uma área de proteção ambiental e, por

\footnotetext{
${ }^{4}$ Este documento (VARELLA; SOUZA, 2017) ficou intitulado como "Parecer técnico sobre a questão socioambiental do Bairro Jardim Social - Paranaguá-PR".
} 
isso, expulsá-los, mesmo que não se tenham planos para realocá-los, aparece como uma solução aos problemas socioambientais causados.

Em outras palavras, buscamos refletir sobre o sistema de interpretação utilizado para sustentar a acusação do Ministério Público sobre os moradores da ocupação Jardim Social, que classifica o território do bairro como uma “área irregular": tal discurso identifica os moradores como impactadores do meio ambiente e, ao mesmo tempo, classifica o espaço ocupado pelos moradores como uma área de Mata Atlântica, não sendo, por isso, passível de regularização fundiária. Cabe, enfim, analisar se é plausível sustentar, como faz o Ministério Público Estadual, que esses moradores sejam definidos como "criminosos" e a ocupação territorial como "irregular" pelo fato de terem cometido, por conjectura, alguma lesão às legislações vigentes ${ }^{5}$.

Este artigo foi organizado em quatro partes, além de uma conclusão final. Na primeira, abordaremos os procedimentos metodológicos adotados para compreender a realidade estudada; na segunda parte, lançamos luz sobre determinados pontos do Processo Civil em questão, que permitem compreender tanto o processo histórico de uso e ocupação do solo quanto as alegações perpetradas pelo Ministério Público. Na sequência, apresentamos a realidade do bairro segundo argumentos técnicos e teóricos vinculados à ótica do Direito à Cidade, que traz em seu bojo a questão socioambiental e que funciona como elemento chave para compreender a realidade parnanguara. Desde essas amarras, poder-se-á, na quarta parte deste artigo, avaliar de maneira mais precisa a operacionalização do direito ambiental neste caso concreto. Por fim, considerando as análises e levantamentos feitos, arguir-se-á acerca da resolução desse conflito territorial, enfatizando um discurso que visa enfrentar a segregação socioespacial parnanguara - e não perpetuá-la, sob uma roupagem sustentável.

\section{Sobre a metodologia de pesquisa}

Como prática de pesquisa, orientamos este trabalho desde ações desenvolvidas pelo Grupo de Pesquisa Identidades Coletivas, Conflitos Territoriais e Educação Emancipadora ${ }^{6}$, o qual tem a

\footnotetext{
5 O Ministério Público enfatiza a "lesão à legislação ambiental vigente" como um dos principais argumentos que sustentam o pedido de liminar inaudita altera pars. Contudo, devemos destacar que, na presente reflexão, objetivamos ampliar esse leque, com fins de incluir outras legislações que servem às ações de uso e ocupação do solo de uma cidade, sem as quais torna-se difícil, senão impossível, operacionalizar qualquer jurisdição de cunho ambiental.

${ }^{6}$ Este grupo denominava-se, a princípio, apenas de "Identidades Coletivas e Conflitos Territoriais no Sul do Brasil", tendo reunido, ao menos desde 2013, pesquisadores, professoras(es) e estudantes que atuavam de modo circunscrito a diferentes instituições (como UFPR Litoral, UFPR, IFPR e UDESC) com movimentos sociais, utilizando, entre outros instrumentos, a cartografia social como metodologia de pesquisa. Em 2016, esse coletivo se formalizou como grupo de pesquisa
} 
produção de conhecimento técnico-científico a partir de metodologias de educação popular ${ }^{7}$, como a pesquisa-ação, também denominada de pesquisa participante (BRANDÃO; BORGES, 2007) e a cartografia social (ALMEIDA, 2008), como uma das principais atividades. Nesse sentido, toda a pesquisa fez-se amarrada a cursos de formação técnica e política, formalmente vinculados a cursos de extensão universitária com diferentes temáticas - assim, desde pelo menos o ano de 2013 passamos a trabalhar com o tema do Direito à Cidade com moradores de algumas ocupações urbanas de Paranaguá.

Assim aconteceu o primeiro contato com a Associação de Moradores do Bairro Jardim Social. No ano de 2015, foi construída junto com os moradores uma Cartografia Social do Bairro, a partir de cursos de extensão e de pesquisas participativas, que permitiram compreender melhor o processo de uso e ocupação social promovido por esses sujeitos coletivos, bem como os conflitos territoriais por eles vivenciados. Esse processo de ensino-pesquisa-extensão, somado à análise documental dos arquivos oficiais aqui apresentados, fundamentam, então, em boa medida aquilo que evidenciaremos neste artigo que, por sua vez, visa traduzir em linguagem acadêmica o discurso que vem sendo sustentado por esses moradores.

Outrossim, arguimos que o processo de construção de um território, como, por exemplo, o Bairro Jardim Social ou a cidade de Paranaguá, depende mormente das relações sociais que estão estabelecidas nesse espaço, em um dado momento histórico - afinal, o território é resultado da interação de múltiplos atores e territorialidades, que se cruzam de maneira não harmoniosa no presente, e que condicionam os processos socioespaciais futuros. Assim, para uma melhor compreensão das diferentes interpretações utilizadas pelos atores no conflito territorial aqui tratado, munimo-nos do uso de técnicas ligadas ao geoprocessamento ${ }^{8}$, visando estabelecer uma aproximação entre o direito ambiental e o Direito à Cidade, a partir dos planejamentos territoriais estatais: foi por esse liame que pudemos comparar dados oficiais do IBGE com o Plano Diretor de Desenvolvimento

vinculado ao CNPQ e sediado no IFPR Paranaguá. Um importante passo foi a adoção de uma ênfase na Educação Emancipadora, utilizando essa categoria como elemento transversal a todas suas ações.

7 A educação popular, ao instrumentalizar-se de pesquisas participantes, possibilita perceber que a "investigação, a educação e a ação social convertem-se em momentos metodológicos de um único processo dirigido à transformação social" (BRANDÃO; BORGES, 2007, p. 55). Nesse sentido, o Grupo de Pesquisa Identidades Coletivas (...) foca em ações educativas que têm em vista, acima de tudo, alterar as relações de desigualdades socioespaciais encontradas no litoral do Paraná.

${ }^{8}$ Geoprocessamento é a terminologia mais utilizada na academia para se referir a técnicas, teorias e práticas que se baseiam no uso de aparatos tecnológicos (como GPS, computadores e softwares de sistemas de informação geográfica) para produzirem informações espaciais georreferenciadas. Tais instrumentos são, atualmente, imprescindíveis no planejamento e gestão territoriais. 


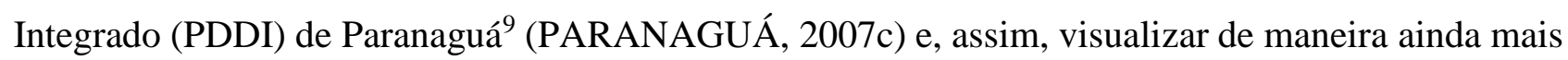
completa a questão socioambiental do município.

\section{Notas sobre o conflito territorial vivido pelos moradores da ocupação Jardim Social}

Para a melhor compreensão do leitor, optamos por dividir este tópico em dois momentos: um primeiro, relativo ao processo histórico de formação do território ora ocupado pelos moradores; e um segundo, que versa sobre a proposta de ação civil perpetrada pelo MPE. Em ambos, a análise documental aparece como a principal metodologia utilizada - mas, frise-se, novamente, foi a participação dos sujeitos nas análises documentais que nos permitiu enxergar as ponderações que seguirão.

\section{Um breve histórico da formação territorial do bairro Jardim Social}

Lembramos, aqui, Santos (2004, p. 189), para quem o território "funciona segundo as leis do atual, mas o passado está presente", ou seja, o espaço existente é resultado de processos sociais passados que o formaram, e, ao mesmo tempo, essas mesmas ações, do passado e do presente, condicionarão as ações do futuro. Logo, a história permite que se compreenda os meandros de formação de um lugar, tornando-o mais inteligível.

Nesse liame, para compreender a situação atual da ocupação Jardim Social precisamos compreender seu processo de formação - remontar, enfim, ao menos sua história mais recente. E uma análise documental, por sorte, nos permite fazer essa empreitada.

Para tanto, uma leitura do lugar em questão depende do levantamento do histórico de proprietários e de usos dados à área, a fim de perceber como o território foi formado. Assim, pode-se ter a década de 1960 como um marco dessa história, na medida em que foi nesse momento que o sr. Hiroshi Oyama e sua esposa, a sra. Missao Oyama, adquiriram um terreno rural, sem benfeitorias, medindo 77,40 metros de frente, por 1000 metros de fundo, totalizando uma área de 77,400 metros quadrados (PARANÁ, 2013, p. 160).

A família nunca chegou a construir, modificar ou investir quaisquer tipos de capital fixo na área - mas, ainda assim, segundo relatos de uma das depoentes no processo, a área passava constantemente por "limpezas", ou seja, havia o corte de espécies nativas. Com o falecimento do

\footnotetext{
${ }^{9}$ Lei complementar $n^{\circ}$ 60, de 2007 (PARANAGUÁ, 2007a), que regulamenta o Plano Diretor de Desenvolvimento Integrado.
} 
casal, por volta dos anos 2000, um dos filhos continuou fazendo esporadicamente as "limpezas" no terreno, sem, de fato, dar uma função social concreta a este - ou seja, sem lhe dar um uso devido, como, por exemplo, o de moradia ou de comércio.

Desde essa informação, pode-se fazer duas afirmações: 1) já nos anos 2000, a área não se apresentava mais como uma "natureza intocada", tampouco a cobertura vegetal existente coincidia com a cobertura vegetal original; 2) a esporadicidade das "limpezas" feitas ao longo do tempo, ainda que não significassem uso direto da área, diante de sua já estabelecida abertura, já permitia interpretar esse espaço como potencialmente passível de ocupação humana.

Cabe ressaltar, de toda a forma, que no momento que essas "limpezas" foram feitas, tal ação não se configurava como crime ambiental, ainda que desde a década de 1980 a noção de impacto ambiental já existisse juridicamente, desde a Política Nacional do Meio Ambiente (BRASIL, 1981); naquele momento não havia sido regulamentada a própria noção de "crime ambiental", que passou a vigorar somente a partir da publicação da Lei de Crimes Ambientais em 1998 (BRASIL, 1998). Mas, frisamos, que indiferente à magnitude e à regulamentação, essas "limpezas" podem ser classificadas categoricamente como um eufemismo da noção de "impacto ambiental", ainda que de pequeno porte, de acordo com a definição dada pela Normativa 01 do Conselho Nacional do Meio Ambiente (BRASIL, 1986), interpretada como

[...] qualquer alteração das propriedades físicas, químicas e biológicas do meio ambiente, causada por qualquer forma de matéria ou energia resultante das atividades humanas que, direta ou indiretamente, afetam: I - a saúde, a segurança e o bem-estar da população; II - as atividades sociais e econômicas; III - a biota; IV as condições estéticas e sanitárias do meio ambiente; V - a qualidade dos recursos ambientais (BRASIL, 1986, grifo nosso).

Paralelamente a essa história de ocupação do lote, cabe abordar a história de (re)produção territorial em outra escala, ou seja, ao nível do município, a fim de procurar elementos que iluminem outros condicionantes que atravessaram o processo aqui analisado. Durante os anos 1990-2000, segundo os cadernos de diagnóstico do Plano Diretor de Desenvolvimento Integrado (PARANAGUÁ, 2007c, p. 36), Paranaguá já apresentava uma alta taxa de urbanização, com mais de 96\% da população vivendo na área urbana; ao mesmo tempo, como bem explicita o Caderno de Diagnósticos Número I (PARANAGUÁ, 2007c, p. 171), as “áreas irregulares”, em 2006, concentravam "quase metade da população urbana, o equivalente a aproximadamente 60 mil habitantes, e ocupam uma extensão de $7 \mathrm{~km}^{2}, 26 \%$ da área urbana" (grifo nosso), de modo que "a situação fundiária de Paranaguá é considerada o maior desafio da administração municipal” (idem). Significa dizer que, sem políticas habitacionais coerentes e eficazes, os moradores mais pobres 
passaram a ser jogados à própria sorte em Paranaguá, utilizando a autoconstrução e a posse da terra como estratégias possíveis para viver nas cidades.

Quaisquer que tenham sido os planos dos proprietários sobre a área, isso se modifica a partir de 2002, quando falece o filho do casal, responsável pela manutenção das "limpezas": o terreno fica, então, “abandonado". Entre 2005 e 2011, os grileiros e especuladores imobiliários passam a agir sobre a área: diferentes atores privados começam a disputar a propriedade desse lote, a fim de gerar renda com a venda da terra, ou seja, emerge um conflito territorial entre aqueles que visavam tão-somente mercantilizar aquele espaço. Em boa medida, esses conflitos podem ser explicados pelos mapas apresentados no PDDI, que demonstram que o crescimento da ocupação urbana parnanguara, a partir dos anos 2000, volta-se à face sul da cidade (PARANAGUÁ, 2007d, p. 15, Mapa 3): logo, o terreno em litígio localiza-se na área de expansão urbana do município, o que significa, entre outras coisas, que o valor de troca dos lotes, desde a década de 2000, começou a ser incrementado pela especulação imobiliária, impulsionado pelos investimentos públicos e privados que passaram a acontecer nessa região (como as instalações de um shopping, de uma universidade, de uma escola e de uma creche, bem como a duplicação da rodovia estadual que liga Paranaguá a Pontal do Paraná).

De toda forma, nesse lapso temporal de seis anos (2005-2011), um empresário parnanguara "esquentou" documentos de propriedade e tentou adonar-se da área (PARANÁ, 2013, p. 336), algo impedido apenas em ação na justiça, perpetrada por herdeiros da família Oyama. Mas esse imbróglio não impediu que o terreno fosse vendido por um dos doze herdeiros, ainda que irregularmente, para um empresário ligado ao ramo imobiliário da cidade: sem uso e valorizada, agentes que visavam mercantilizar a área passaram a disputar entre si a propriedade da terra. Em todos esses anos, indiferente ao ator, a área nunca foi utilizada ou ocupada.

Isso só se dá no ano de 2010, quando os primeiros cidadãos pobres vieram a se instalar na área: acabaram adquirindo os terrenos de um grileiro, que retomou a limpeza da área e, clandestinamente, loteou e vendeu o terreno, sem dar nenhuma garantia legal aos moradores. Sem ter outra opção de compra, por falta de condições econômicas, esses moradores passaram, finalmente, a fazer cumprir a função social que foi estabelecida pela municipalidade em seu planejamento territorial para aquela região onde se localizava o lote, segundo a Lei Complementar Municipal n 60, de 2007 (PARANAGUÁ, 2007): em outras palavras, o terreno passou a ser utilizado com fins de moradia para população de baixa renda.

Tendo em vista esse histórico, precisa-se entender que um lote ou uma cidade, como frações de um território, deve ter seu processo de formação ligado à noção de multiterritório (HAESBAERT, 2014), de modo que se possa compreender a intencionalidade que perpassa as ações dos diferentes 
sujeitos que interagem em um processo de des-re-territorialização: afinal, se são múltiplos atores que o formam, então são igualmente múltiplos os interesses e as estratégias postas em jogo. Assim, podese dizer que a ocupação da área onde se localiza o Bairro Jardim Social resulta da ação de pelo menos três atores distintos, que não podem ser confundidos entre si: os antigos proprietários, os grileiros e os moradores.

Nos autos do processo analisado (PARANÁ, 2013), o "Espólio de Hiroshi Oyama” representa os herdeiros dos antigos proprietários. Atualmente, contestam a área, adquirida por volta da década de 1960. Ainda segundo os autos, cabe frisar que esses antigos proprietários somente nos anos 2000 demonstraram interesse em utilizar a área: foram quarenta anos sem se fazer cumprir a função social dessa propriedade que, neste ínterim, fora especulada e, por isso, acabou sendo supervalorizada com relação ao seu valor venal - em suma, esses atores buscaram, historicamente, apenas lucros mercadológicos, advindos da concorrência intraurbana por lotes regulares e dos investimentos públicos e privados realizados nas imediações.

Já em 2009 (PARANÁ, 2013, p. 141) alguns grileiros fizeram "limpezas" na área, antes da chegada dos moradores: visando, qual os especuladores, apenas gerar renda com a terra, lucrando com a irregularidade de distribuição do solo urbano ou urbanizável. Esses atores desmataram a área sem pensar em ocupá-la, mas, do contrário, tramaram apenas vendê-la, ao maior preço possível. Qual os antigos proprietários, esses atores visaram tão somente beneficiar-se do valor de troca do lote, em que a mercantilização da terra aparece como a intenção maior.

Somente a partir de 2011 é que o cenário da área se altera e ela passa a ser ocupada exclusivamente por moradores - ou seja, sujeitos cuja relação com espaço dá-se majoritariamente pelo valor de uso, e não de troca. Em grande medida, tratam-se de trabalhadoras sem condições econômicas para alcançar o direito à cidade a partir da compra de um lote regularizado pelo Estado: mas, nem por isso, podem ser interpretados como "cidadãos menores" que outros moradores da cidade. A formação territorial do Bairro Jardim Social representou, então, para essas pessoas, a oportunidade de conseguir uma moradia para viver com suas famílias, nas mínimas condições possíveis: aquele espaço, mesmo sem assistência governamental e sob constante ameaças de despejo, aparece, ainda, como a melhor possibilidade para manterem uma vida digna. É por isso que o Centro de Referência em Assistência Social (CRAS) da Vila Garcia afirmou nos autos que a população dessa área e das proximidades é caracterizada como "em situação de vulnerabilidade social" (PARANÁ, 2013, p. 782).

A diferenciação entre os atores que produzem o território da cidade mostra-se fundamental para compreensão do conflito territorial vivido pelos moradores do Bairro Jardim Social: entre os 
especuladores e os grileiros que visavam obter algum tipo de lucro com a venda da área (valor de troca) estão os moradores, que visam tão somente alcançar o direito à moradia (valor de uso). Não são as mesmas pessoas, nem têm as mesmas pretensões - tanto é que a partir do momento em que o Bairro Jardim Social vê cessarem as grilagens, sendo ocupado exclusivamente por moradores, o Batalhão de Polícia Ambiental fez um Boletim de Ocorrência registrando que "não foram efetuadas novas ocupações recentes e desmates" na área (PARANÁ, 2013, p. 180) - e isso porque a ocupação já havia se consolidado, não havendo mais necessidade de realizar as limpezas.

Somente nos foi possível discriminar esses atores (antigos proprietários, grileiros e moradores) pelos diálogos estabelecidos com os moradores. Fotos pessoais que os moradores possuíam, e que datavam do começo da ocupação (após a grilagem, portanto), serviu como uma prova de que, quando ocuparam a área, esta já estava "limpa" - quem realizou a derrubada da Mata Atlântica, assim, não foram os moradores, mas os antigos proprietários e os grileiros. Os moradores começaram, a partir de então, a produzir um contradiscurso àquele discurso dominante, que negava o direito à cidade.

Desconsiderando esses detalhes relativos à complexidade do processo de formação socioespacial e dos diferentes atores envolvidos na formação de um multiterritório, o MPE, em 2013, promoveu uma ação contra os proprietários do terreno, bem como contra os moradores do Bairro Jardim Social (PARANÁ, 2013, p. 04-05). Desde essa proposição de ação civil, ainda em curso, o MPE requereu que os acusados cessassem imediatamente as ações impactadoras do meio ambiente, bem como que fossem condenados a pagar indenização pelos impactos ambientais causados e a recuperar a área degradada. Por fim, demandou a obrigatoriedade da "desocupação da área objeto da presente ação e a promoção da demolição de todas as edificações implantadas" (PARANÁ, 2013, p. 32) - esse último, como se pode notar, acaba sendo aplicado de maneira mais direta e onerosa sobre os moradores do Bairro Jardim Social. É sobre essa alegação de crime ambiental que nos atentaremos no próximo tópico.

\section{Uma síntese da ação civil do MPE}

O promotor de justiça baseia a ação civil, em termos operacionais, tomando como premissa para suas alegações, as características naturais do bioma da área em questão, correspondente, segundo constam os autos, a um fragmento de Mata Atlântica. Destarte, a região deveria enquadrar-se como uma área natural protegida, tal qual apregoa a Lei da Mata Atlântica (BRASIL, 2006) - diante de tal classificação, não haveria quaisquer possibilidades de se regularizar uma ocupação, segundo a promotoria. Aliás, chegou a afirmar o promotor que: 
Verifica-se, assim, que além dos graves danos ambientais promovidos por meio do desmatamento de Floresta Atlântica e do dever de sua reparação integral, há também patente clandestinidade e ilegalidade do loteamento em fase da implantação, já que em razão dessa clandestinidade, não há e nem poderia haver: a) aprovação da Prefeitura Municipal de Paranaguá; b) registro do loteamento aprovado no Cartório de Registro de Imóveis; e c) o atendimento aos requisitos legais previstos na Lei Federal no 6766/79 e na Lei Complementar nº 66, de 27 de agosto de 2007 (PARANÁ, 2013, p. 10. Grifo nosso).

Segundo a promotoria, a região em questão sequer poderia ser loteada e regularizada pela prefeitura, visto se tratar de um fragmento de Mata Atlântica - destarte, o loteamento existente é considerado, em si, como um crime, visto não ter seguido os trâmites previstos nas leis de parcelamento do solo urbano: para o promotor, poder-se-ia afirmar "cabalmente a inviabilidade de implantação de um loteamento no imóvel de propriedade dos requeridos” (PARANÁ, 2013, p. 11).

Desde a Lei Federal n ${ }^{\circ} 11.428$ (BRASIL, 2006), o Estado passou a proteger o Bioma da Mata Atlântica pela diversidade de espécies, animais e vegetais que se encontram nesse ecossistema muitas, aliás, existem exclusivamente nessas áreas e correm risco de serem extintas. Nesse sentido, para definir objetivamente a abrangência espacial de aplicação dessa lei, fora promulgado o Decreto Federal n $n^{\circ} 6.660$ (BRASIL, 2008), que estabeleceu o mapa oficial de distribuição geográfica da Mata Atlântica. Abaixo, apresentamos um esquema que visa representar a aplicabilidade dessa lei para o estado do Paraná:

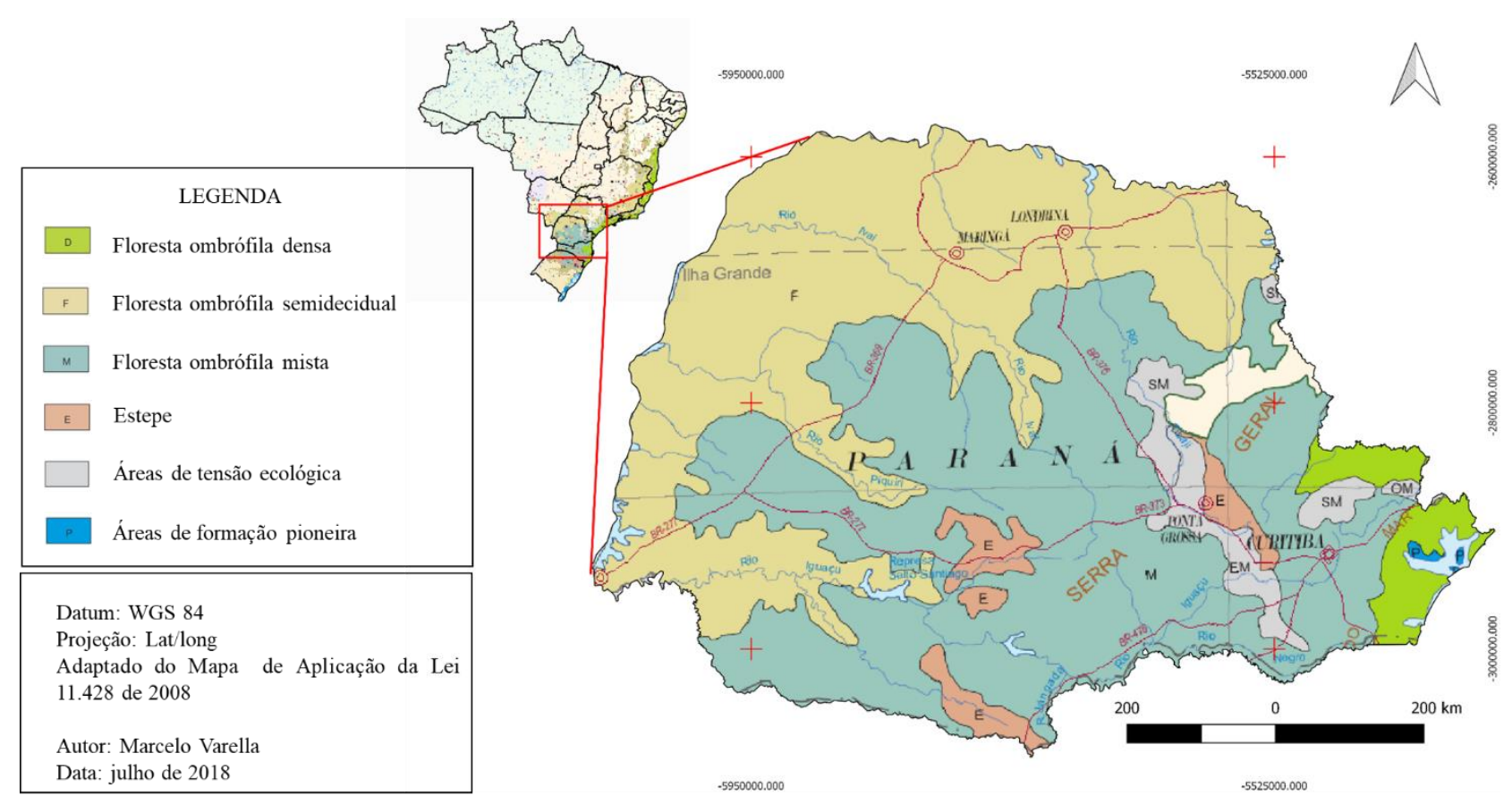

FIGURA 1 - CLASSIFICAÇÃO DO PARANÁ SEGUNDO A LEI FEDERAL Nº 11.428, DE 2006. FONTE: VARELLA (2018). 
Note-se, na figura acima, que todo o estado do Paraná, incluindo, evidentemente, o litoral, está classificado com coberturas vegetacionais condizentes com a Mata Atlântica; mais objetivamente, em uma escala maior, pode-se notar que a região litorânea está demarcada como uma área de "Floresta ombrófila densa". Nesse sentido, se essa lei fosse aplicada exatamente segundo esse mapa, poder-se-ia concluir que todo o estado é uma área de proteção ambiental e, portanto, qualquer ocupação deveria ser considerada como irregular. Vale ressaltar que, segundo o sítio do IBGE, o mapa estabelecido como o "oficial” pela Lei da Mata Atlântica foi produzido com "base técnica do Mapa de Vegetação do Brasil (IBGE, 2004) e do Mapa de Biomas do Brasil, primeira aproximação (IBGE, 2004)" $" 10$ - em suma, trata-se de uma leitura da lei que prioriza as nuances ambientais do território, com prejuízo às leituras relativas à produção socioespacial: e é essa linha de raciocínio que utiliza a promotoria.

Nas folhas 10 e 11 dos autos, o Ministério Público Estadual coloca que dever-se-ia levar em consideração, ainda, além do fator da degradação ambiental dada pela supressão vegetal, outras violações graves que esse "loteamento clandestino" causaria à legislação ambiental, como o lançamento de esgoto e o depósito irregular de resíduos sólidos - porém, esquece-se o Ministério Público Estadual que esse é um problema generalizado na cidade, não sendo exatamente uma ação dos moradores ou dos "loteamentos clandestinos", mas, sim, resultado da inação da Prefeitura de Paranaguá: deve-se ter em mente que ainda hoje a cidade não possui um sistema de coleta seletiva efetivo e utiliza o sistema do "lixão" (ou seja, conformidade nula com quaisquer legislações ambientais vigentes) para fazer a disposição final de seus resíduos (PARANAGUÁ, 2017d, p. 21); além disso, quanto ao esgotamento sanitário, mais de $30 \%$ da população não possui ligação com a rede pública (PARANAGUÁ, 2017c, p. 336). Nesse sentido, esse fato dá-se muito mais por uma violência praticada pelo Estado sobre a qual, vale ressaltar, os moradores apresentam-se como vítimas, do que desses sujeitos contra a cidade $^{11}$ : se há crime ambiental, aqui, certamente o autor vem a ser o próprio Estado, e não os cidadãos.

De toda a forma, essas acabaram sendo as premissas consideradas durante o ajuizamento, afinando-se às interpretações dadas pela promotoria:

\footnotetext{
${ }^{10}$ Vide o sítio do órgão disponível em: <https://ww2.ibge.gov.br/home/geociencias/recursosnaturais/mapas_doc6.shtm $\geq$. Acesso em: dez. 2017.

${ }^{11}$ É por isso que Oliven (1986, p. 24) geralmente não considera incluso na categoria “violência” questões como acidentes causados pela falta de fiscalização ou pela corrupção pública - essas são violências comuns na cidade e são causadas mormente pela ação do Estado.
} 
Dos relatórios confeccionados pelo Instituto Ambiental do Paraná - IAP e pela Polícia Ambiental, bem como das demais provas juntadas, constata-se a existência de invasão coletiva da área particular, no Bairro Porto Seguro, próximo à rodovia PR 407 - Km 09, bem como o desmatamento de vegetação nativa pertencente ao Bioma da Mata Atlântica secundária, que se encontra em estágio médio e avançado de regeneração, não passível de licenciamento, com base no artigo $3^{\circ}$, item II, alíneas A, B, D, G e H, todas da Resolução 10/93 do CONAMA. (Juiz Fernando Bardelli Silva Fischer, em procedimento ordinário de 24 de junho de 2013 disponível em PARANÁ, 2013, p. 591. Grifo nosso).

Defere, diante do exposto, então, a liminar:

[...] tão somente para determinar a suspenção imediata de qualquer atividade de corte ou supressão de vegetação no Bioma de Mata Atlântica, assim como a movimentação de solo ou quaisquer novas obras de melhoria ou de infraestrutura, ou qualquer alteração ao ambiente na área objeto da presente demanda (Juiz Fernando Bardelli Silva Fischer, em procedimento ordinário de 24 de junho de 2013 disponível em PARANÁ, 2013, p. 591).

Como se vê, prevaleceu a análise ambiental nessa decisão, interpretada de cima para baixo, e que coloca sobre os moradores o risco de sofrerem uma desterritorialização forçada. Para problematizar mais a fundo esse conflito territorial, utilizaremos o próximo tópico para fazer uma análise socioambiental do conflito, destacando as condições territoriais que permeiam esta temática.

\section{Uma análise socioambiental do conflito territorial ou o lado social da perspectiva ambiental}

Este tópico centra-se nas análises e interpretações documentais realizadas junto com os moradores do Bairro Jardim Social, a fim de tentar inverter o discurso promovido pelo Ministério Público Estadual. Para tanto, partindo de um olhar que visava enxergar o planejamento territorial que permitisse alcançar o direito à cidade, e não a somente o controle do território, atravessamos as legislações relativas à regulamentação do uso e ocupação do solo urbano. Visando explicitar melhor essas reflexões, dividimos este tópico em três subitens complementares: iniciaremos tratando da temática socioambiental, partindo das leis e princípios que regem o planejamento territorial municipal atualmente; na sequência, apresentaremos os efeitos da atual política urbana municipal, visando compreender se há ou não crime ambiental promovido pelos moradores do Bairro Jardim Social; e por fim, ponderaremos sobre a ocupação feita no bairro citado, visando compreender possíveis encaminhamentos ao conflito territorial existente, frisando, acima de tudo, o direito à cidade. 


\section{Sociedade, espaço e meio ambiente: notas sobre o direito à cidade em Paranaguá}

O direito à cidade pode ser entendido, segundo Lefevbre (2001), como o humanismo e a democracia próprias das cidades, sendo, portanto, historicamente construído. Logo, tal perspectiva visa pensar as formas pelas quais homens e mulheres urbanos apropriam-se da cidade a qual contribuíram para construir e que, dialeticamente, os constituem como ser social. Nesse sentido, a própria cidade e a "vida cotidiana se tornam obra, apropriação, valor de uso (e não valor de troca)" (LEFEVBRE, 2001, p. 140). É nesse sentido que opera o direito à cidade: pensando a cidade a partir não de seus atributos mercadológicos (como se faz de praxe em uma sociedade capitalista), mas, sim, de seu valor de uso, ou seja, considerando os sujeitos como cidadãos, e não como consumidores.

Durante a construção da cartografia social dos moradores do Bairro Jardim Social, o direito à cidade apareceu como uma categoria importante para mobilizar o contradiscurso daqueles sujeitos. Vale lembrar que, historicamente, essa temática sempre esteve associada aos debates sobre a democratização do acesso à moradia e ao controle territorial nas cidades. Desde a Constituição Federal de 1988 (BRASIL, 1988), quando o Movimento Social por Reforma Urbana colocou essas demanda mais enfaticamente em pauta ${ }^{12}$, o direito à cidade ficou objetivado no arcabouço jurídico do Estado a partir de dois artigos: o artigo 182, que versa sobre a aplicação do usucapião, e o 183, que coloca os "planos diretores" como um dos principais instrumentos de planejamento territorial para alguns municípios brasileiros.

A regulamentação desses dois artigos levou mais de dez anos para ser feita, ocorrendo somente em 2001, com a Lei Federal no 10.257 (BRASIL, 2001), conhecida como o Estatuto da Cidade ${ }^{13}$. Em boa verdade, é desde essa lei que se pode pensar na aplicabilidade das leis ambientais, uma vez que os planos diretores regulamentados segundo o Estatuto associam a temática ambiental ao direito à cidade - é o que versa o parágrafo único do artigo $1^{\circ}$ do Estatuto da Cidade:

Para todos os efeitos, esta Lei, denominada Estatuto da Cidade, estabelece normas de ordem pública e interesse social que regulam o uso da propriedade urbana em prol do bem coletivo, da segurança e do bem-estar dos cidadãos, bem como do equilíbrio ambiental (BRASIL, 2001, art. $1^{\circ}$, parágrafo único).

Pode-se notar que a lei citada não trata apenas da questão social, uma vez que engloba normativas sobre o meio ambiente: com fins de se promover o acesso aos direitos coletivos básicos e o ambiente natural sustentável (entram nesta conta, portanto, as questões da moradia, ambiental e da

\footnotetext{
${ }^{12} \mathrm{Na}$ verdade, foram feitas muitas propostas, mas apenas essas duas foram atendidas. Para saber mais sobre a história do direito à cidade no Brasil, pode-se consultar Souza (2005).

${ }^{13}$ Isso se coloca logo no $1^{\circ}$ artigo da citada lei: "Na execução da política urbana, de que tratam os arts. 182 e 183 da Constituição Federal, será aplicado o previsto nesta Lei” (BRASIL, 2001, art. $1^{\circ}$ ).
} 
democratização do acesso à infraestrutura de uso coletivo, como água tratada, luz elétrica, esgotamento sanitário e coleta de resíduos sólidos), visando produzir uma "cidade sustentável” (artigo $2^{\circ}$, inciso primeiro ${ }^{14}$ ). Assim, ao visar a sustentabilidade, a questão ambiental está incorporada ao Estatuto da Cidade e seus respectivos planos diretores (BRASIL, 2001, art. 1º $^{\circ}$ inciso primeiro).

Tendo em vista esses aspectos, os moradores do Bairro Jardim Social passaram a analisar coletivamente os mapas do plano diretor de Paranaguá, compreendidos como um dos principais instrumentos existentes para a execução dos planejamentos territoriais, segundo Souza (2003). Nesse sentido, em diversas ocasiões, o Grupo de pesquisa Identidades Coletivas [...] participou de reuniões, assembleias e debates coletivos sobre a temática junto com os moradores, nos quais foram apresentados não apenas os mapas, mas trechos do Plano Diretor de Desenvolvimento Integrado de Paranaguá e leis relacionadas. Dentre todos os debates, certamente aqueles que rodavam em torno dos mapas de zoneamento de uso e ocupação do solo foram os que mais despertaram interesse e atenção dos moradores - questioná-los passou a ser, por fim, uma estratégia coletiva aos sujeitos. Nesses mapas, o território da cidade é representado a partir de diferentes zonas, cada qual expressando uma classificação e uma função diferentes; em seu conjunto, as zonas formam o "zoneamento municipal", que serve para criar aquilo que se pode compreender como o "ordenamento territorial" da cidade. Em outras palavras, esses mapas expressam as intenções do Estado para promover o controle sobre a produção territorial no município.

Mas não é só isso. Os zoneamentos representam, ainda, objetivamente, aquilo que o Estatuto da Cidade passou a denominar de "função social", aplicável em todo o território de uma cidade. Nesse sentido, o planejamento territorial promovido pelos planos diretores deve, a partir de seus zoneamentos, considerar valores sociais às áreas da cidade que não são definidos meramente por atributos mercadológicos (valor de troca). Para o Estatuto da Cidade, uma propriedade/cidade cumpre sua função social quando seu uso atende às exigências expressas nos zoneamentos do plano diretor é o que se lê expressamente em seu artigo 39:

A propriedade urbana cumpre sua função social quando atende às exigências fundamentais de ordenação da cidade expressas no plano diretor, assegurando o atendimento das necessidades dos cidadãos quanto à qualidade de vida, à justiça social e ao desenvolvimento das atividades econômicas (BRASIL, 2001, art. 39).

Foi nessa linha de pensamento que os moradores do Bairro construíram a cartografia social: interpretando o território a partir das legislações relativas ao direito à cidade, e não unicamente a

\footnotetext{
${ }^{14}$ Lê-se que a política urbana visa, dentre outros objetivos, garantir "o direito a cidades sustentáveis, entendido como o direito à terra urbana, à moradia, ao saneamento ambiental, à infra-estrutura urbana, ao transporte e aos serviços públicos, ao trabalho e ao lazer, para as presentes e futuras gerações" (BRASIL, 2001, art. $1^{\circ}$, inciso primeiro).
} 
partir da legislação ambiental. Para saber se os moradores cometeram algum crime ambiental, portanto, precisa-se, antes, conhecer qual "zona" foi utilizada no PDDI para classificar o lote do Bairro, bem como qual "função social” foi prevista para a área em questão.

Parece primordial, aqui, o raciocínio de Santos (2004), para quem o espaço é preenchido pelas ações sociais: assim o faz o plano diretor, que classifica o território segundo um sistema interpretativo específico. Vejamos, no próximo tópico, qual é a função social utilizada no plano diretor para classificar o Bairro e, assim, tentar garantir, ao mesmo tempo, a proteção de suas áreas naturais e o direito à cidade.

\section{Um planejamento territorial em prol do direito à cidade: uma revisitada ao PDDI}

É importante compreender que, aqui, não entraremos em detalhes mais minuciosos sobre a construção teórica do plano diretor de Paranaguá, visto que fugiria do escopo da análise. Pretendemos tão somente, portanto, apontar para os efeitos do ordenamento territorial parnanguara sobre o território do Bairro Jardim Social, enfatizando alguns mapas que nos permitam compreender a aplicação das leis ambientais desde o plano diretor.

Antes de tudo, torna-se imprescindível reconhecer o valor desse instrumento de planejamento urbano, sem o qual a gestão territorial de um município dar-se-ia somente pela aplicação das leis federais ou estaduais, no sentido estrito da letra - e, no caso do litoral do Paraná, isso levaria à impossibilidade de se fazer qualquer tipo de gestão e planejamento territorial. Como em outros municípios do litoral paranaense, Paranaguá possui fatias consideráveis do território demarcadas como "áreas naturais protegidas" - segundo Denardin et al. (2009, p. 190), o município possui mais de 56\% de sua área classificada dessa forma, variando entre Unidades de Conservação, Reservas Legais, Áreas de Proteção Permanente e Terras Indígenas. Um plano diretor deve considerar essas informações, refinando as legislações postas em uma macroescala (nível da nação) para a microescala (escala municipal): se o já citado mapa da lei da Mata Atlântica fosse aplicado literalmente na realidade parnanguara, a ocupação de todo o município seria considerada ilegal.

Por isso, consideramos que interpretar todo o litoral paranaense como uma área protegida de Mata Atlântica acaba causando uma aparente homogeneização da complexidade socioespacial e, por isso, parece-nos ser uma interpretação parcelar das legislações que versam sobre a configuração territorial de uma cidade. E isso porque as leituras que não se atentam ao valor social atribuído ao espaço, ou seja, à função social atribuída pelos zoneamentos dos planos diretores, não compreendem a racionalidade municipal sobre o ordenamento territorial. O mapa abaixo ajuda a compreender a 
complexidade dessa área, que não pode ser confundida pura e simplesmente, de maneira homogênea, como se fosse um fragmento de Mata Atlântica:

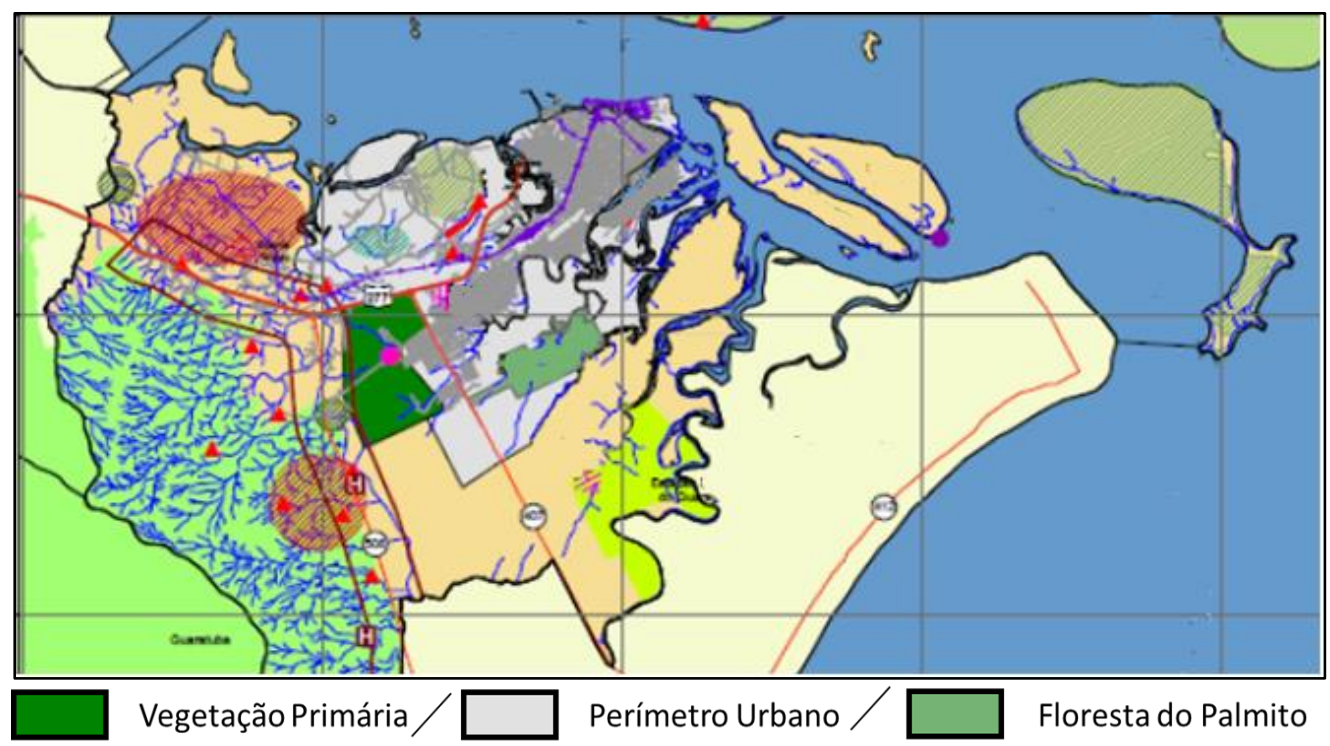

FIGURA 2 - ANÁLISE TERRITORIAL. EM DESTAQUE, LEGENDAS CORRESPONDENTES À "VEGETAÇÃO PRIMÁRIA", "PERÍMETRO URBANO" E "FLORETA ESTADUAL DO PALMITO". FONTE: Adaptado de PARANAGUÁ (2007d).

A imagem acima permite compreender melhor a estratégia municipal para produzir uma cidade sustentável, de acordo com o plano diretor. Relativo ao diagnóstico territorial do município, o mapa acima identifica uma gama de potencialidades e de atividades presentes no território parnanguara: como se pode notar, há apenas uma área classificada como vegetação primária ${ }^{15}$, ou seja, a única no perímetro urbano que ainda contém cobertura florestal nativa, do Bioma da Mata Atlântica. O mesmo mapa mostra, ainda, a Floresta do Palmito - representada apenas para orientar o leitor, auxiliando-o a localizar o Bairro Jardim Social: conforme aponta os autos, o Bairro localiza-se a 500 metros dessa Unidade de Conservação (PARANÁ, 2013, p. 579). Fica fácil notar, com isso, que o Bairro Jardim Social está localizado em uma “área urbana” (número 2, na imagem anterior), e não em um fragmento de "Mata Atlântica", como pressupõe a leitura da promotoria. Prova disso é o “mapa proposta 4" do PDDI, representado a seguir:

\footnotetext{
${ }^{15}$ Segundo o artigo $2^{\circ}$ da Resolução no 02 de 1994 do Conama, uma vegetação primária é definida como sendo "de máxima expressão local, com grande diversidade biológica, sendo os efeitos das ações antrópicas mínimos, a ponto de não afetar significativamente suas características originais de estrutura e de espécies".
} 


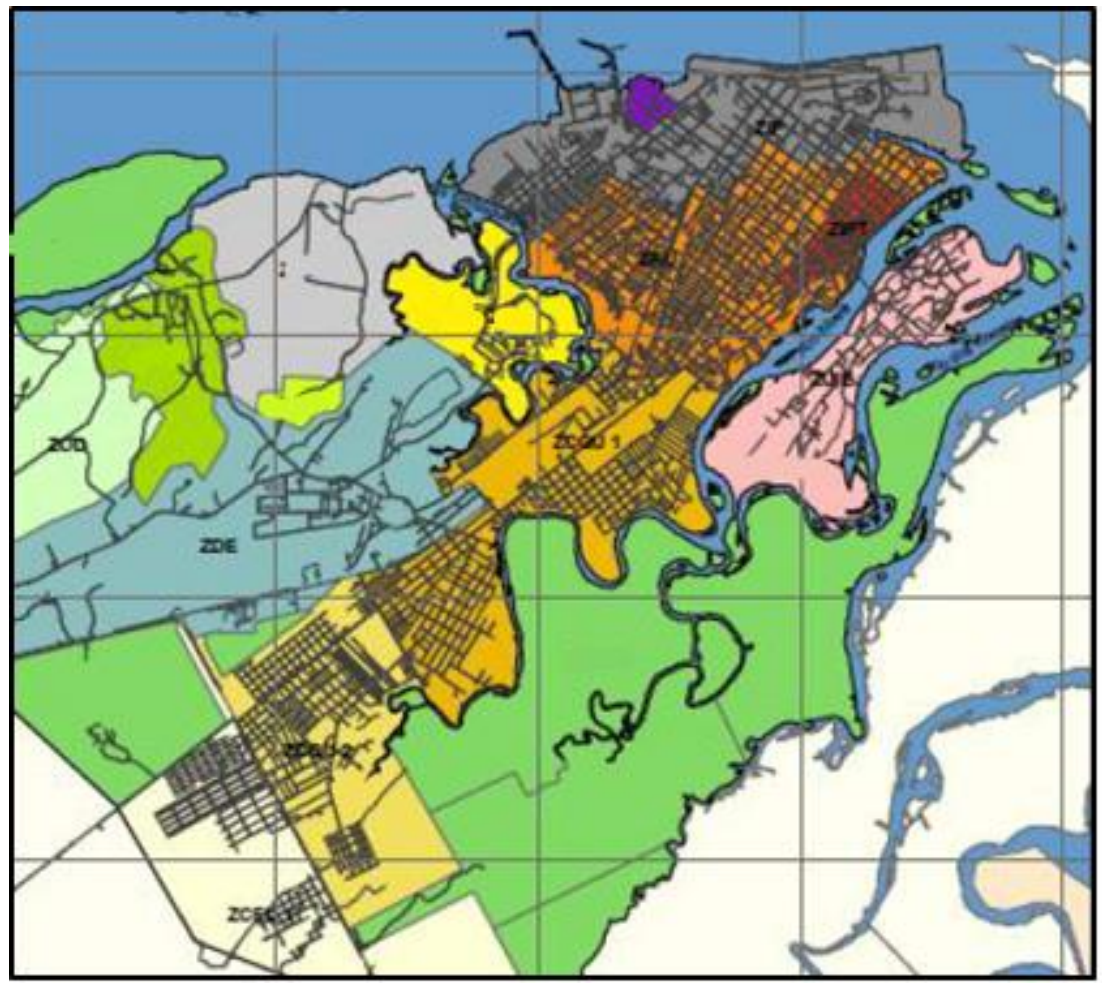

ZCQ 2 - Zona de Consolidação e Qualificação Urbana 2

FIGURA 3 - SOBRE A PROPOSTA DE ZONEAMENTO URBANO. ABAIXO, DESTAQUE PARA A ZONA ONDE SE LOCALIZA O BAIRRO JARDIM SOCIAL - TRATA-SE DE UMA "ZONA DE CONSOLIDAÇÃO E QUALIFICAÇÃO URBANA 2".

FONTE: Adaptado de PARANAGUÁ (2007d).

O mapa acima tornou-se muito conhecido entre os moradores do Bairro Jardim Social. Constantemente debatido, representa sintética e espacialmente a racionalidade municipal quanto ao uso e ocupação do solo na cidade, desde seu "zoneamento urbano". A região onde se localiza o Bairro Jardim Social, nesse sentido, está classificada como um Zona de Consolidação e Qualificação Urbana do tipo 2 (ZCQ 2) - sem entrar em detalhes sobre essa classificação, ressaltamos que se trata de uma área onde a prefeitura pretende investir (qualificar) para consolidar a urbanização já existente e que se encontra em áreas de fragilidade ambiental. Em suma, não se trata, então, de uma área cujo planejamento vise manter inocupada e sem uso - pelo contrário: segundo a Lei Complementar $\mathrm{n}^{\circ} 62$ (PARANAGUÁ, 2007b) que rege o zoneamento urbano municipal, a função social de uma ZCQ 2 “caracteriza-se pela predominância de uso misto, carência de equipamentos públicos, existência de áreas consolidadas e de áreas para ocupação com fragilidade ambiental” (grifo nosso).

Logo, não há crime ambiental em ocupar essa área - se há crime, foi no passado, quando grileiros e antigos proprietários fizeram "limpezas” na área: aí, sim, se poderia objetivamente 
encontrar um crime ${ }^{16}$. Mas, ocupar uma área urbana, cuja função social é voltada justamente para consolidar a moradia urbana desde investimentos estatais, oras, isso não pode ser configurado como crime ambiental - do contrário, trata-se de fazer cumprir a função social da propriedade daquele lote.

Os moradores passaram, então, a contrapor o discurso do MPE a partir do plano diretor de Paranaguá: não invadiam uma área de proteção ambiental, mas, sim, ocupavam espaços destinados à moradia - nos debates, argumentavam que o mapa mostrava que o Bairro se localizava na zona de cor "mostardinha", correspondente à classificação da área como ZCQ 2.

Multiterritórios e a questão ambiental: iluminando a intencionalidade que perpassa a ação social

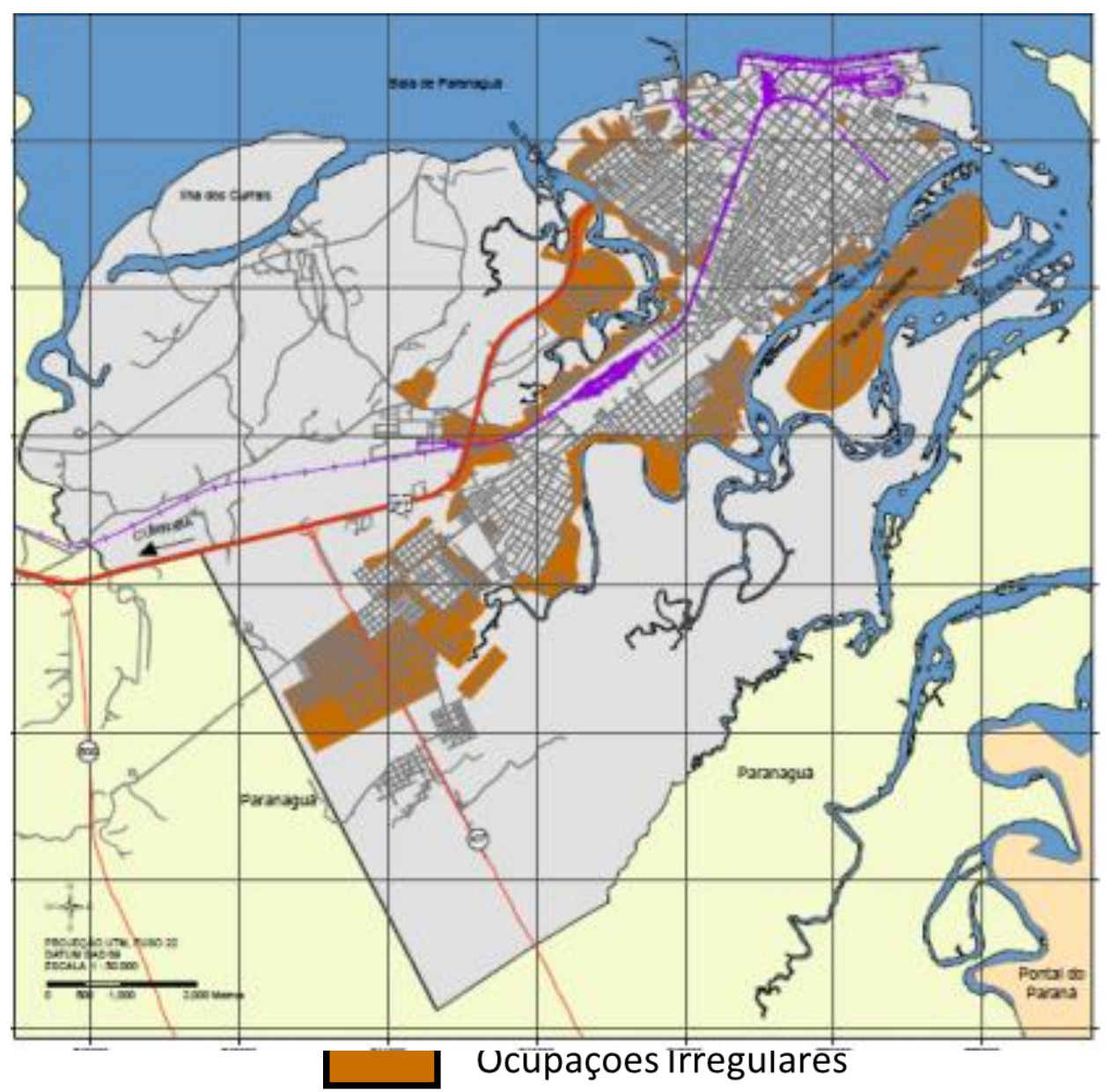

FIGURA 4 - IDENTIFICAÇÃO DAS OCUPAÇÕES IRREGULARES ${ }^{17}$ (1970-1990) FONTE: PARANAGUÁ (2007d).

\footnotetext{
${ }^{16}$ De toda a sorte, algumas "limpezas" nos anos 2000, feitas pela sra. Maria (ou a seu mando), possuem liberações ambientais - ao menos no ano de 2006 (PARANÁ, 2013, p. 305). Aquelas feitas pelo sr. Hiroshi, na década de 1990, não apresentaram nenhum tipo de liberação ou autorização - ao menos não constam nos autos.

${ }^{17}$ Nessas áreas, segundo o próprio PDDI, vivem 60 mil pessoas, quase metade da população parnanguara.
} 
O conflito territorial vivenciado pelos moradores do Bairro Jardim Social explícita uma realidade comum no município de Paranaguá: a desigualdade socioespacial, marcada pelo parco acesso a terrenos regularizados pelos moradores mais pobres. Como já afirmado neste documento, o PDDI contabilizou que quase metade da população parnanguara vive em situação jurídica similar a dos moradores do Bairro Jardim Social. O resultado pode ser vislumbrado no mapa acima: a malha urbana parnanguara cerceada, de todos os lados, por ocupações irregulares.

Vale ressaltar que essa é a realidade de muitos municípios brasileiros, em que a desigualdade socioespacial aparece como produto e, ao mesmo tempo, engrenagem do modo de produção capitalista das cidades hodiernas. Como bem lembra Souza (2005), na atual conjuntura, viver "aqui" ou "ali" não corresponde a um processo consciente de escolha, mas, sim, às possibilidades historicamente construídas. A desigualdade socioespacial torna-se explícita no espaço, que se torna socialmente segregado: criam-se espaços do medo, do preconceito, da intolerância - espaços nos quais a punição e o controle aparecem como a prática mais comum por parte das elites e do Estado. Assim, as "disparidades estruturais na distribuição da riqueza socialmente gerada e do poder" (SOUZA, 2005, p. 84) nas sociedades capitalista acabam sendo retroalimentadas pela segregação socioespacial.

Cabe questionar, aqui, a capacidade que tem o Estado de produzir uma cidade sustentável na qual opera o modo de produção capitalista e, mais ainda, quais são os efeitos e intencionalidades que perpassam o pedido de reintegração de posse do Bairro Jardim Social - afinal, remover os moradores da área não significa acabar com o problema ambiental decorrente da ocupação irregular em Paranaguá, mas, pelo contrário, poderá apenas aumentá-lo. Que não se perca de vista que a territorialização é um processo contínuo: ao desterritorializar os moradores de um lugar, leva-os, necessariamente, a reterritorializar-se em outro (HAESBAERT, 2014). Cabe, então, perguntar: mas se reterritorializarão onde? Onde é que sujeitos sem condições econômicas poderão adquirir uma área em Paranaguá, hoje, senão em uma outra ou nova ocupação irregular?

Essa é uma questão complicada, ainda mais em um cenário sem políticas habitacionais precisas. E se não há respostas a essas questões, então talvez se possa compreender que a ideia de "sustentabilidade" apresentada pela promotoria possui, como efeito maior, a reprodução da segregação socioespacial, e não uma solução aos problemas sociais, ambientais e territoriais da cidade. Tal perspectiva parece estar próxima daquilo que Waldman (1992) denominou de "capitalismo verde", ou de uma "ambientalismo institucional”, em que as práticas de mercantilização do território e da vida tingem-se discursivamente de "sustentáveis". 
Além disso, se a mesma proposta do Ministério Público Estadual fosse replicada para todas as áreas irregulares da cidade, então ter-se-ia que expulsar 60.000 pessoas de suas casas e regenerar a Floresta Atlântica (que sequer existe como floresta primária hoje, como mostramos neste artigo). Após essa reintegração de posse (expulsão dos moradores), essas mesmas pessoas precisariam encontrar novos $7.000 \mathrm{~m}^{2}$ para ocupar - afinal, não existe possibilidade de um ser humano viver sem espaço. Como se vê, o problema habitacional, enfim, quando é tratado estritamente pela lógica ambiental e pelo viés punitivo, apenas tende a reproduzir o quadro de violências diárias as quais o Estado vem historicamente submetendo seus cidadãos mais pobres.

Logo, pode-se considerar que a organização social que vem sendo promovida pelos moradores do Bairro Jardim Social presta um serviço público inestimável ao se autoidentificar espacial e identitariamente ao poder público, visto que, assim, pode auxiliar esses agentes externos a compreender o processo de produção territorial do lugar, em toda sua complexidade. Vale ressaltar que essa organização luta pela regularização fundiária da área, visando conquistar o acesso à moradia digna e condizente com as leis ambientais: se ocupam a área, não o fazem visando impactar o meio ambiente ou lucrar, mas, sim, porque precisam viver, reproduzir-se cultural e materialmente. Para quem dialoga mais a fundo com esses sujeitos, ou lê a cartografia social produzida pelos moradores (acessível a partir do contato com eles), percebe que esse coletivo possui preocupações com a temática ambiental: basta frisar que dos mais de $77.400 \mathrm{~m}^{2}$ originais do terreno, $23.220 \mathrm{~m}^{2}$ foram reservados à preservação, ou seja, foram comunitariamente separados para permanecerem inocupados. No que depender desse poder popular, aquela área se regenerará e, um dia, tornará a ser Floresta Atlântica.

Utilizando o mesmo categorial proposto por Waldman (1992), pode-se interpretar que as ações sociais promovidas pelos moradores do Bairro em prol da regularização fundiária estão próximas à vertente combativa do ambientalismo, visto que enfrentam as ações e os discursos que intentam resolver os problemas socioespaciais e ambientais das cidades a partir da reprodução do capitalismo. Ao invés de mercantilizar o espaço, a cidade e a vida, as ações coletivas desses sujeitos visam compatibilizar o direito à moradia com as questões ambientais, interpretando-as como inseparáveis.

O processo histórico de ocupação da área apresentado por esses sujeitos permite, como dito anteriormente, compreender a multiplicidade de atores envolvidos na produção do território: logo, pode-se notar que o que difere os atores entre si é justamente o tipo de ação desenvolvida por cada um desses sujeitos - enquanto os antigos proprietários e os grileiros visaram utilizar o espaço tratando-o como uma mercadoria (segundo seu valor de troca), os moradores do Bairro intencionam viver no local, tratando-o enfaticamente como condição de vida (ou seja, desde seu valor de uso). 
Nesse sentido, punir cidadãos por não terem onde morar não parece ser uma forma coerente de fazer justiça, tampouco de atingir a sustentabilidade. Para fugir da leitura jurídica colocada pela promotoria, pode-se analisar o conflito territorial do Bairro Jardim Social a partir da análise do dolo dos sujeitos, ou seja, da intenção de corromper ou não a lei, para, então, determinar se há ou não crime ambiental nas ações dos moradores. Como base, pode-se utilizar o relatório do Ministro Celso Limongi, da $6^{\mathrm{a}}$ Turma do Supremo Tribunal de Justiça (BRASIL, STJ, 2011):

Ora, o depoimento mostra que o dolo era de construir moradia para si e sua família, mesmo ciente de que a área não lhe pertencia, mas isso não corresponde ao dolo necessário à subsunção da conduta ao tipo do art. 40 da Lei n. 9.60598, pois uma coisa é invadir terra pública, e outra, bem distinta, é causar dolosamente dano ambiental. Quando o preso causa dano com o intuito de fugir, temos reiteradamente dito que o delito de dano não se configura, e isto me parece óbvio, pois no direito penal o que se incrimina é a intencionalidade dos fins. O que se tem nos autos é que o paciente não tinha onde morar e, incapaz de pagar o preço exorbitante que é praticado no Distrito Federal, viu-se na contingência de, como tantos outros, invadir área pública para construir sua moradia. É este um caso de política habitacional e não de política criminal. Lembremos que a via estrutural foi invadida, autoridades públicas retiraram com violência os ocupantes da área [houve mortes] e, afinal, rendeu-se à realidade: regularizou a posse e construiu ali uma cidade satélite (BRASIL, STJ, 2011. Grifo nosso).

Como se percebe, para o Desembargador é a intencionalidade que incrimina uma ação, desde o direito penal - é o fim, o objetivo da ação, em suma, que deve ser levado em consideração. Punir “moradores por morarem”, conseguintemente, não parece ser justificativa para caracterizar um "crime ambiental": o dolo foi morar, e não destruir a natureza. Mais que política criminal, precisa-se, sim, de política habitacional - e, aqui, o direito à cidade aparece como uma prática que não deveria ser ignorada pelos agentes do Estado.

De maneira objetiva, graças às pesquisas desenvolvidas junto com os moradores, pode-se identificar com exatidão quem são os atores envolvidos no processo de formação do Bairro Jardim Social: os moradores do Bairro chegaram apenas por volta do ano de 2011, sendo que foram outros atores, em tempos anteriores, os responsáveis pela supressão vegetacional sem autorização do Estado, causando os impactos ambientais na área, citados pela promotoria. Destarte, quando se deu a chegada dos moradores, a área não se apresentava mais como uma vegetação primária - diversas espécies nativas já haviam sido cortadas nas "limpezas", realizadas pelos proprietários e grileiros. Mais que falta de conhecimento científico, de legislações e instrumentos técnicos, parece que as questões da habitação e da segregação socioespacial em Paranaguá têm mais a ver com uma estratégia das classes dominantes que com um problema que está sendo enfrentando pelo Estado. 


\section{Considerações finais}

A questão ambiental não pode ser pensada fora do contexto histórico das sociedades atuais quando se fala em "impacto ambiental", deve-se sempre questionar, como pressupõe Waldman (1992), quem é o ator responsável pela ação. O movimento ambientalista, enfim, não é homogêneo, havendo diferentes intenções e planos envolvendo a temática. Como coloca Martins (2014):

[ ...] se por um lado as políticas urbanas parecem incorporar a questão ambiental, por outro, o discurso ambiental vem sendo frequentemente utilizado pelos governos, empresas, instituições e mesmo pela opinião pública para sustentar práticas e projetos que mais têm acirrado os conflitos sociais e as injustiças ambientais do que enfrentado adequadamente a questão ambiental (MARTINS, 2014, p. 261).

Os moradores do Bairro Jardim Social conhecem bem essa realidade. Desde a autoorganização, criaram estratégias coletivas para se apropriar de conhecimentos técnicos e jurídicos capazes de enfrentar o discurso dominante, em especial aquele propalado pelo Ministério Público Estadual na ação civil contra os moradores do Bairro. Passaram a argumentar que se localizavam em uma zona de cor "mostardinha", referindo-se ao PDDI que, contrariando a interpretação do MPE, serve para designar a área do Bairro como uma Zona de Consolidação e Qualificação Urbana do tipo 2, propícia justamente à ocupação, e não como uma “ocupação irregular”.

O processo histórico de produção do território do Bairro, documentado pelos moradores na cartografia social, apresenta nuances elementares à compreensão do conflito territorial vivenciado pelos moradores: as ocupações irregulares, produzidas direta e indiretamente por proprietários de terra que não fazem cumprir a função social de seus terrenos, e por grileiros que lucram com a mediação da venda de áreas irregulares, representam no espaço a desigualdade e a segregação socioespacial em Paranaguá. Se a ideia da promotoria fosse replicada para outras áreas irregulares da cidade, a prefeitura teria que encontrar espaço e recursos técnicos, estruturais e monetários (que não existem) para fazer a mesma ação com as outras 60 mil pessoas que vivem em situação semelhante trata-se de uma empreitada bastante homérica.

Por fim, como tratado neste artigo, a reintegração de posse em si não resolve, sequer momentaneamente, a questão da habitação para os moradores do Bairro, nem a questão ambiental para a cidade, uma vez que, sendo a habitação algo imprescindível à reprodução da vida, esses sujeitos teriam de ocupar uma nova área tão logo fossem despejados. Sem políticas habitacionais e sem condições monetárias para adquirir um lote regularizado, possivelmente terão de ocupar uma área em 
condições tão ou mais precárias que as atuais - causando tantos ou mais impactos ambientais que os que causam atualmente: seria, enfim, um verdadeiro trabalho de Sísifo, logo, interminável.

A decisão deferida pela Justiça para o caso dos moradores do Bairro ainda está na forma de uma liminar - significa, portanto, que não se trata, ainda, da decisão final. Este artigo buscou, então, iluminar a complexidade do conflito territorial em destaque, apontando para uma linha de raciocínio técnico, científico e jurídico produzida junto com os moradores do Bairro Jardim Social, e que visou enfatizar o direito à cidade como instrumento para solucionar tal cenário litigioso. Daí a necessidade de que, nas próximas audiências de conciliação, a Defensoria Pública do Estado do Paraná e moradores defendam a suspensão da liminar relativa à reintegração de posse por impactos ambientais, sugerida pelo Ministério Público Estadual.

Ao mesmo tempo, desde a perspectiva do direito à cidade, vale lembrar que os moradores devem cobrar dos técnicos que serão contratados pela prefeitura de Paranaguá para atualizar o PDDI, que o Bairro Jardim Social tenha seus limites geográficos classificado como uma Zona de Especial Interesse Social (ZEIS), demonstrando o interesse público em regularizar a área para habitação social. Deve-se lembrar que em 2017 o PDDI completou dez anos e, por isso, precisa, agora, ser revisto e atualizado.

Enfim, enquanto o direito à cidade for renegado, invariavelmente o direito ambiental estará fadado à falência, uma vez que, no cenário atual, desterritorializar um morador pobre significa empurrá-lo a uma nova aventura, marcada pela reterritorialização em novas áreas, possivelmente adquiridas irregularmente por grileiros que, por sua vez, podem ter desmatado mais Mata Atlântica. Mais do que operar o direito verticalmente, de cima para a baixo, o Estado, em todas suas instâncias, precisa aprender e planejar o território com os "de baixo", enfatizando a participação social como instrumento básico à produção de cidades mais justas (social e espacialmente) e sustentáveis. Do contrário, a cidade continuará sendo tratada como mercadoria por aqueles que não dependem do território para viver e, por isso, visam apenas gerar renda da terra, incrementada pela especulação imobiliária, pela venda de lotes irregulares aos mais pobres e pelas repressões do Estado.

\section{Referências}

AlmeIDA, A. W. B. Antropologia dos Archivos da Amazônia. Rio de Janeiro: Casa 8, 2008.

BRANDÃO, C. R.; BORGES, M. C. A Pesquisa Participante: um momento da educação popular. Revista. Educ. Popular, Uberlândia, v. 6, p. 51-62, jan./dez. 2007. 
BRASIL. Constituição (1988). Constituição: República Federativa do Brasil. Brasília, DF: Senado Federal, 1988.

BRASIL. Decreto $n^{\circ}$ 6.660, de 21 de novembro de 2008. Regulamenta dispositivos da Lei $n^{\circ} 11.428$, de 22 de dezembro de 2006, que dispõe sobre a utilização e proteção da vegetação nativa do Bioma Mata Atlântica. Diário Oficial da União, Brasília, DF, 24 nov. 2008. Seção 1, p. 1.

BRASIL. Lei n ${ }^{\circ}$ 6.938, de 31 de agosto de 1981. Dispõe sobre a Política Nacional do Meio Ambiente, seus fins e mecanismos de formulação e aplicação, e dá outras providências. Diário Oficial da União, Brasília, DF, 31 ago. 1981. Seção 1, p. 16509.

BRASIL. Lei $\mathrm{n}^{\circ}$ 9.605, de 12 de fevereiro de 1998. Dispõe sobras as sanções penais e administrativas derivadas de condutas e atividades lesivas ao meio ambiente, e dá outras providências. Diário Oficial da União, Brasília, DF, 12 fev. 1998. Seção 1, p. 1.

BRASIL. Lei no 10.257, de 2001. Regulamenta os Arts. 182 e 183 da Constituição Federal, estabelece diretrizes gerais da política urbana e dá outras providências. Diário Oficial da União, Brasília, DF, 11 jul. 2001. Seção 1, p. 1.

BRASIL. Lei $n^{\circ} 11.428$, de 22 de dezembro de 2006. Dispõe sobre a utilização e proteção da vegetação nativa do Bioma Mata Atlântica, e dá outras providências. Diário Oficial da União, Brasília, DF, 26 dez. 2006. Seção 1, p. 1.

BRASIL. Resolução Conama no 001, de 23 de janeiro de 1986. Dispõe sobre critérios básicos e diretrizes gerais para a avaliação de impacto ambiental. Diário Oficial da União, Brasília, DF, 17 fev. 1986. Seção 1, p. 2548-2549.

BRASIL. Resolução Conama $n^{\circ}$ 002, de 28 de março de 1994. Define formações vegetais primárias e estágios sucessionais de vegetação secundária, com finalidade de orientar os procedimentos de licenciamento de exploração da vegetação nativa no Estado do Paraná. Diário Oficial da União no 59, Brasília, DF, 28 mar. 1994. Seção 1, p. 4513-4514.

BRASIL. Superior Tribunal de Justiça. Habeas Corpus $n^{\circ}$ 124820/DF, da $6^{a}$ Turma. Penal. Relator Desembargador Convocado, Min. Celso Limongi, DJE de 22 ago. 2011. Disponível em: <https://bit.ly/2S1pqgh>. Acesso em: jun. 2017.

DENARDIN, V. F. et al. Distribuição de benefícios ecossistêmicos: o caso do ICMS-Ecológico no litoral paranaense. REDES, Santa Cruz do Sul, v. 13, n. 2, p. 184 -198, maio/ago. 2009.

HAESBAERT, R. Viver no limite: território e multi/transterritorialidade em tempos de insegurança e contenção. Rio de Janeiro: Bertrand Brasil, 2014.

LEFEBVRE, H. O direito à cidade. São Paulo: Centauro, 2001.

MARTINS, M. L. R. Elementos para pensar a questão ambiental urbana. In: LIMONAD, E.; CASTRO, E. (Orgs.). Um novo planejamento para um novo Brasil? Rio de Janeiro: Letra Capital, 2014. p. 257-272.

OLIVEN, R. G. Violência e cultura no Brasil. 3. ed. São Paulo: Vozes, 1986. 
PARANÁ. Poder Judiciário do Estado do Paraná. $1^{\text {a }}$ Vara Civil da Comarca de Paranaguá. Processo civil no 0009430-05.2013.8.0129. Ministério Público, Adriana Lucia Martins Lobo, Emerson Luiz Blankemburg, Espólio de Hiroshi Oyama, grupo de pessoas que integra a ocupação da propriedade (lote $n^{\circ} 2$, transcrição ${ }^{\circ}$ 13.877), Maria Aparecida Silva Oyama, Defensoria Pública do Estado do Paraná, 15/05/2013.

PARANÁ. Defensoria Pública do Estado do Paraná - DPPR. Ofício número 50/2017 (ao professor da Universidade Federal do Paraná, Marcelo Cunha Varella). DPPR, 2017.

PARANAGUÁ. Lei Complementar nº 60, de 23 de agosto de 2007. Institui o Plano Diretor de Desenvolvimento Integrado, estabelece objetivos, instrumentos e diretrizes para as ações de planejamento no Município de Paranaguá e dá outras providências. Diário Oficial do Município de Paranaguá, Paranaguá, PR, 23 ago. 2007a.

PARANAGUÁ. Lei Complementar n 62, de 27 de agosto de 2007. Institui o zoneamento de uso e ocupação do solo do município de Paranaguá, e dá outras providências. Diário Oficial do Município de Paranaguá, Paranaguá, PR, 27 ago. 2007b.

PARANAGUÁ. Plano Diretor de Desenvolvimento Integrado de Paranaguá - PDDI Paranaguá, v. l. Análises temáticas e diagnóstico - contexto municipal. 406 f. Universidade Federal do Paranál Fundação da Universidade Federal do Paraná/Prefeitura Municipal de Paranaguá, Paranaguá, PR, 2007c.

PARANAGUÁ. Plano Diretor de Desenvolvimento Integrado de Paranaguá - PDDI Paranaguá, v. V. Mapas. 66 f. Universidade Federal do Paraná/Fundação da Universidade Federal do Paraná/ Prefeitura Municipal de Paranaguá, Paranaguá, PR, 2007d.

SANTOS, Milton. Por uma geografia nova: da crítica da geografia a uma geografia crítica. 6. ed. São Paulo: USP, 2004.

SOUZA, M. L. Mudar a cidade: uma introdução crítica ao planejamento e à gestão urbanos. 3. ed. Rio de Janeiro: Bertrand Brasil, 2003.

SOUZA, M. L. ABC do desenvolvimento urbano. 2. ed. Rio de Janeiro: Bertrand Brasil, 2005.

VARELLA, M. C.; SOUZA, R. M. Parecer Técnico sobre a questão socioambiental do Bairro Jardim Social - Paranaguá, PR. 26 f. Matinhos, 2017.

WALDMAN, M. Movimento ecológico: combativo ou de resultados? In: Ecologia e lutas sociais no Brasil. São Paulo: Contexto, 1992, pp. 27-45.

Artigo recebido em 14/05/2018. Aceito para publicação em 17/10/2018. 